\title{
Kajian Teknis Pengembangan Budidaya Bawang Merah (Allium Ascalonicum L.) Di Kecamatan Belitang III Kabupaten OKU Timur
}

\author{
Munajat, Andi Astoro \\ Dosen Universita Baturaja \\ Jln. Ratu Penghulu Karang Sari No. 02301. Baturaja. OKU. Sumatera Selatan \\ Email : munajat.ub@gmail.com andifeee33@gmail.com
}

\begin{abstract}
ABSTRAK
Tujuan dari penelitian ini adalah untuk: 1) mengetahui kelayakan finansial budidaya bawang merah di Kecamatan Belitang III Kabupaten OKU Timur, 2) mengetahui respon masyarakat terhadap rencana pengembangan budidaya bawang merah di Kecamatan Belitang III Kabupaten OKU Timur. Hasil penelitian menunjukkan bahwa usaha budidaya bawang merah dalam satu kali musim tanam mengeluarkan biaya produksi sebesar Rp 410.323.853 diperoleh penerimaan sebesar Rp 475.200.000 sehingga diperoleh pendapatan sebesar Rp 64.876.147 dengan nilai BEP (harga) sebesar Rp 18.996/kg dan BEP (produksi) sebesar $2.251 \mathrm{~kg}$. Selanjutnya usaha budidaya bawang merah di Keecamatan Belitang III Kabupaten OKU layak (feasible) secara finansial untuk dikembangkan, hal ini dapat diketahui dari perhitungan nilai NPV sebesar Rp 170.315.520., nilai IRR sebesar 12,49\% dan nilai Net B/C sebesar 1,68. Respon masyarakat terhadap rencana pengembangan budidaya bawang merah adalah siap/setuju dengan nilai index $79,3 \%$. Masyarakat desa Dadi Rejo yang Merupakan desa di sekitar tempat budidaya bawang merah memberikan respon Setuju karena melihat kedaan wilayah yang cocok untuk di tanami bawang merah seperti Tanahnya subur, Pengairan dari irigasi yang baik, Cuaca dan iklim yang cocok untuk budidaya bawang merah, Memiliki penyinaran sinar matahari lebih dari 75\% sehingga Masyarakat Desa Dadi Rejo Setuju Dengan Adanya pengembangan budidaya bawang merah.
\end{abstract}

Kata Kunci : Bawang Merah (Allium Ascalonicum L.), Break Event Point (BEP), Kelayakan Bisnis.

\section{PENDAHULUAN}

\section{A. Latar Belakang}

Bawang merah merupakan salah satu jenis sayuran yang sangat dikenal di Indonesia sebagai bumbu penyedap masakan. Umbi bawang merah mengandung minyak atsiri yang diketahui mampu menimbulkan aroma khas dan memberikan rasa gurih pada masakan. Umbi bawang merah mengandung protein $1,5 \%$, lemak $0,3 \%$ dan karbohidrat $9,2 \%$. Komponen gizi lainnya yang terkandung dalam bawang merah antara lain 50 UI karoten, $30 \mathrm{mg}$ thiamin, 0,04 $\mathrm{mg}$ riboflavin, $20 \mathrm{mg}$ niasin, $9 \mathrm{mg}$ asam askorbat, $334 \mathrm{mg}$ kalium, 0,8 mg zat besi dan $40 \mathrm{mg}$ fosfor (Wibowo, 2006).

Tingkat permintaan dan kebutuhan konsumsi bawang merah yang tinggi menjadikan komoditas ini menguntungkan jika diusahakan. Konsumsi bawang merah di Indonesia per kapita per tahun mencapai 4,56 kilogram atau 0,38 kilogram per kapita per bulan. Tingginya permintaan bawang merah yang terus meningkat tidak hanya terjadi di pasar dalam negeri, tetapi berpeluang juga untuk ekspor (Ditjen Holtikultura, 2004). Data dari Badan Pusat Statistik Indonesia (2013), menyebutkan bahwa produksi bawang merah pada tahun 2013 di Indonesia dengan luas lahan keseluruhan 98.937 ha adalah sebesar 101,07 ton. Sedangkan produksi bawang merah di Provinsi Riau pada tahun 2013 dengan luas lahan 3 ha adalah 12 ton.

Tanaman bawang merah merupakan sumber pendapatan bagi petani dan memberikan kontribusi yang tinggi terhadap pengembangan ekonomi pada beberapa wilayah (Balitbangtan, 2006). Produksi umbi bawang merah khusunya di Sumatera Selatan tahun 2014 sebesar 151 ton/ha mengalami penurunan sebanyak 67 ton $(30.67 \%)$ dibandingkan pada tahun 2013 (BPS, 2015).

Penurunan produksi tersebut disebabkan oleh menurunnya luas panen diSumatera Selatan sebesar 6 ha $(20.00 \%)$ dan produktivitasnya juga turun sebesar 0.97 ton/Ha (13.34\%). Penghasil bawang merah di Sumatera Selatan tahun 2014 terdapat di empat kabupaten, yaitu Kabupaten Ogan KomeringUlu, Kabupaten Muara Enim, Kabupaten Musi Rawas dan Kabupaten OKU Selatan (BPS, 2015).

Tabel 1. Luas Lahan dan Produksi Kelompok penerima manfaat bantuan pemerintah Kawasan Bawang Merah Kabupaten OKU Timur, 2019.

\begin{tabular}{|c|c|c|c|c|c|}
\hline Kecamatan & Desa & $\underset{\text { tani }}{\text { Klelompok }}$ & $\begin{array}{c}\text { Luas } \\
\text { Tanam } \\
\text { (Ha) }\end{array}$ & $\begin{array}{c}\text { Luas } \\
\text { Panen } \\
\text { (Ha) }\end{array}$ & $\begin{array}{l}\text { Produksi } \\
\text { (Ton) }\end{array}$ \\
\hline \multirow{4}{*}{$\begin{array}{l}\text { Semendawai } \\
\text { suku III }\end{array}$} & Karang & Sri Cumpti & a & a & 172 \\
\hline & Karang & Dana Pelita & 1 & 1 & 8 \\
\hline & Endah & Serba Usaha & 3 & 3 & 36 \\
\hline & $\begin{array}{l}\text { Suka Mulya } \\
\text { Jaya Mulya }\end{array}$ & Cinta Maju & 3 & 0 & 0 \\
\hline \multirow{3}{*}{ Belitang III } & Suka Negara & Suka Maju & 2 & 2 & 14,8 \\
\hline & Suka Negara & Suka Maju II & 4 & 4 & $\begin{array}{l}46,0 \\
46,4\end{array}$ \\
\hline & Karya Maju & $\begin{array}{l}\text { Gemah } \\
\text { Ripah } 11\end{array}$ & 3 & 3 & 58,2 \\
\hline Belitang & & & & & \\
\hline $\begin{array}{l}\text { Madang } \\
\text { Raya }\end{array}$ & Marga Cinta & Kancil & 2 & 2 & 18,7 \\
\hline $\begin{array}{l}\text { Semendawai } \\
\text { Timur }\end{array}$ & $\begin{array}{l}\text { Karang } \\
\text { Anyar }\end{array}$ & Campur Sari & 1 & 1 & 6,36 \\
\hline $\begin{array}{l}\text { Bunga } \\
\text { Mayang }\end{array}$ & Peracak & $\begin{array}{l}\text { Muda } \\
\text { Harapan }\end{array}$ & 1 & 1 & 2,69 \\
\hline
\end{tabular}


Sumber : Dinas Pertanian Kabupaten OKU Timur, 2019.

Kabupaten OKU Timur Selain sebagai lumbung beras, juga melakukan budidaya tanaman Hortikultura salah satunya budidaya bawang merah, karena permintaan bawang merah ini sangat besar di pasaran apalagi saat tertentu, permintaan yang meningkat setiap tahun sesuai demgan pertumbuhan ekonomi, jumlah penduduk dan pendapatan masyarakat. Budidaya bawang merah di OKU Timur salah satunya kecamatan Belitang III, terdapat kelompok tani Suka Maju yang memproduksi bawang merah dari tahun 2018, respon masyarakat cukup mendukung dengan adanya budidaya tersebut terbukti dengan makin banyaknya petani yang menggeluti usaha budidaya bawang merah.

\section{B. Rumusan Masalah}

Berdasarkan latar belakang dan uraian di atas, adapun permasalahan yang menarik untuk diteliti adalah sebagai berikut :

1. Bagaimana kelayakan finansial budidaya bawang merah di Kecamatan Belitang III Kabupaten OKU Timur.

2. Bagaimana respon masyarakat terhadap rencana pengembangan budidaya bawang merah di Kecamatan Belitang III Kabupaten OKU Timur.

\section{Tujuan dan Kegunaan}

Berdasarkan latar belakang dan rumusan masalah di atas, maka tujuan penelitian ini adalah untuk :

1. Mengetahui kelayakan finansial budidaya bawang merah di Kecamatan Belitang III Kabupaten OKU Timur.

2. Mengetahui respon masyarakat terhadap rencana pengembangan budidaya bawang merah di Kecamatan Belitang III Kabupaten OKU Timur.

Hasil penelitian ini diharapkan menjadi bahan informasi dan manfaat dalam analisis Tingkat Keuntungan usaha bawang merah.

\section{KERANGKA PEMIKIRAN}

\section{A. Model Pendekatan}

Kementerian Pertanian, permintaan bawang merah secara nasional cenderung meningkat dari tahun ke tahun, begitu pula produksi bawang merah. Pada tahun 2007 misalnya permintaan bawang merah sebesar 909.853 ton dengan produksi 807.000 ton, tahun 2008 permintaan meningkat menjadi 934.301 ton dengan produksi 855.000 ton. Pada tahun 2009, kebutuhan bawang merah di Indonesia mencapai 936.103 ton dengan produksi 965.164 ton dan meningkat pada tahun 2010 menjadi 976.284 ton dengan produksi 1.048.228 ton. Penurunan produksi terjadi pada tahun 2011 yaitu produksi sebesar 893.124 ton. Peningkatan produksi bawang merah diprediksi terjadi pada tahun 2012 menjadi 960.179 ton (Ditjen Holtikultura, 2011).

Tingkat permintaan dan kebutuhan konsumsi bawang merah yang tinggi menjadikan komoditas ini menguntungkan jika diusahakan. Konsumsi bawang merah di Indonesia per kapita per tahun mencapai 4,56 kilogram atau 0,38 kilogram per kapita per bulan. Tingginya permintaan bawang merah yang terus meningkat tidak hanya terjadi di pasar dalam negeri, tetapi berpeluang juga untuk ekspor (Ditjen Holtikultura, 2004). Pendapatan petani bawang merah cukup besar jika pada saat harga bawang merah menyentuh harga $\mathrm{Rp} 20.000 / \mathrm{Kg}$, produksi 10 ton, berarti akan didapat Rp 200.000.000 per hektar dan modalnya Rp 160.000.000. dibagi 3 bulan (masa tunggu panen).

Arahan konseptual dan asumsi-asumsi yang terkandung dalam uraian di atas memungkinkan tersususunnya suatu kerangka berfikir argumentatif berupa model pendekatan, bagan alir pada gambar berikut :

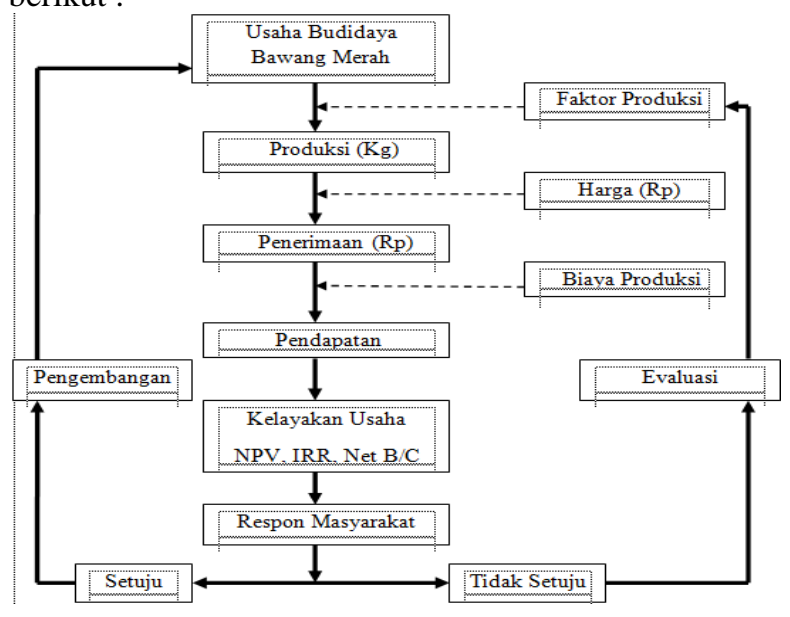

Keterangan :

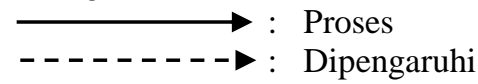

Gambar 1. Model Pendekatan Diagramatis Keuntungan Usaha Bawang Merah.

\section{B. Hipotesis}

Berdasarkan teori dan kerangka pemikiran teoritis yang telah diuraikan sebelumnya, maka hipotesis yang dirumuskan dalam penelitian ini adalah sebagai berikut :

1. Bahwa usaha budidaya bawang merah layak untuk dikembangkan.

2. Bahwa respon masyarakat mengenai rencana pengembangan budidaya bawang merah di Kecamatan Belitang III setuju/siap.

\section{Batasan-Batasan}

Untuk menghindari luasnya pokok bahasan dalam penelitian ini, maka diperlukan batasan masalah. Adapun batasan masalah dalam penelitian ini adalah sebagai berikut :

1. Penelitian dilaksanakan di Belitang III Kabupaten OKU Timur. 
2. Responden adalah Kelompok tani bawang merah Desa Suka Negara dan petani di Desa Dadi Rejo kecamatan Belitang III.

3. Proses produksi adalah lamanya waktu yang digunakan untuk menghasilkan bawang merah (2 bulan).

4. Biaya Produksi adalah sejumlah biaya yang dikeluarkan pembudidaya pada proses produksi yang terdiri dari biaya tetap dan biaya variabel (Rp/pp).

5. Biaya tetap adalah biaya yang dikeluarkan dalam kegiatan usahatani bawang merah, dimana besar kecilnya tidak mempengaruhi besar kecilnya output yang diperoleh per satu kali produksi dengan satuan Rupiah (Rp/pp).

6. Biaya variabel adalah biaya yang dikeluarkan dalam kegiatan usahatani bawang merah yang besar kecilnya mempengaruhi jumlah produksi yang dihasilkan persatu kali produksi dengan satuan Rupiah (Rp/pp).

7. Produk adalah suatu barang atau jasa yang dihasilkan dalam satu produksi yaitu bawang merah (Kg).

8. Harga jual adalah harga jual yag diterima pada saat penjualan, diukur dengan satuan Rupiah setiap satuan berat $(\mathrm{Rp} / \mathrm{kg})$.

9. Penerimaan adalah jumlah uang yang diterima dari hasil pemjualan usahatani bawang merah.

10. Pendapatan adalah penerimaan yang diperoleh dari usahatani bawang merah, setelah dikurangi dengan seluruh biaya yang dikeluarkan (Rp/pp).

11. Analisis kelayakan usaha yang digunakan pada penelitian ini adalah untuk menguji layak atau tidaknya suatu usaha pengembangan budidaya bawang merah.

12. Sekala likert adalah tolak ukur untuk mengetahui respon masyarakat terhadap pengembangan budidaya bawang merah.

\section{PELAKSANAAN PENELITIAN}

\section{A. Tempat dan Waktu}

Penelitian ini telah dilaksanakan di Kecamatan Belitang III Kabupaten OKU Timur. Adapun pemilihan lokasi tempat penelitian di tentukan secara sengaja (purposive) dengan mempertimbangkan bahwa di Desa Suka Negara dan Desa Dadi Rejo Kecamatan Belitang III merupakan kecamatan yang penduduknya mayoritas petani dan sudah banyak yang mengusahakan bawang merah . penelitian ini dilaksanakan pada bulan Maret sampai Mei 2020.

\section{B. Metode Penelitian dan Penarikan Contoh}

Metode yang digunakan dalam penelitian ini adalah metode studi kasus, menurut Walgito (2010), menyatakan bahwa studi kasus merupakan suatu metode untuk menyelidiki atau mempelajari suatu kejadian mengenai perseorangan atau usaha. Sample dalam penelitian ini yaitu budidaya bawang merah yang berada di Desa Suka Negara Kecamatan Belitang III Kabupaten OKU Timur.

Menurut Sugiyono (2012), menyatakan sampling jenuh (sensus) adalah teknik penentuan sampel apabila semua anggota populasi digunakan sebagai sample. Dalam hal ini responden petani budidaya bawang merah di Desa Suka Negara Kecamatan Belitang III Kabupaten OKU Timur adalah respoden satu-satunya. Sedangkan untuk respon masyarakat masyarakat terhadap pengembangan budidaya bawang merah di Kecamatan Belitang III yaitu masyarakat yang berada di Desa Dadi Rejo digunakan metode survey dengan intensitas sampling sebesar 5\% sehingga didapat jumlah sample 29 orang dari total populasi 568 orang. Dengan melihat potensi yang berada di Desa Dadi Rejo yaitu :

a). Lahan pertanian yang luas untuk di jadikan budidaya bawang merah.

b). Tanahnya subur.

c). Pengairan dari irigasi yang baik.

d). Cuaca dan iklim yang cocok untuk budidaya bawang merah

e). Memiliki penyinaran sinar matahari lebih dari $75 \%$.

\section{Metode Pengumpulan Data}

Data yang dikumpulkan dalam penelitian ini terdiri dari data primer dan data sekunder. Data primer diperoleh dari observasi dan wawancara langsung dengan pihak-pihak yang menjadi objek penelitian yaitu petani bawang merah yang berada di Desa Suka Negara dan petani di Desa Dadi Rejo Kecamatan Belitang III Kabupaten OKU Timur dengan menggunakan data quisioner atau data pertanyaan. Sedangkan data sekunder diperoleh dari lembagalembaga yang ada hubungannya dengan penelitian.

\section{Metode Pengolahan Data}

Menurut Soekartawi (2002), mengemukakan bahwa data yang diperoleh dari lapangan akan diolah secara tabulasi dan dilanjutkan untuk menjawab tujuan dengan menggunakan rumus sebagai berikut :

1). Menghitung biaya produksi (Suratiyah, 2006), sebagai berikut :

\section{$\mathbf{T C}=\mathbf{F C}+\mathbf{V C}$}

Keterangan :

$\mathrm{TC}=$ Total Cost (Total Biaya)

$\mathrm{FC}=$ Fixed Cost (Biaya Tetap)

$\mathrm{VC}=$ Variable Cost (Biaya Tidak Tetap)

2). Menghitung penerimaan (Suratiyah, 2006), sebagai berikut :

$\mathrm{TR}=\mathrm{P} \times \mathrm{Y}$

Dimana :

$\mathrm{TR}=$ Total Revenue $($ Peneriman $)$

$\mathrm{P}=$ Price (Harga Komoditi)

$\mathrm{Y}=$ Yield ( Jumlah Produksi)

3). Menghitung pendapatan sebagai berikut :

$\mathrm{I}=\mathrm{TR}-\mathrm{TC}$

Dimana :

$\mathrm{I}=$ Income (Pendapatan)

$\mathrm{TR}=$ Total Revenue $($ Peneriman $)$ 
$\mathrm{TC}=$ Total Cost $($ Total Biaya $)$

4). Menghitung Break Event Point (Suratiyah, 2006), sebagai berikut :

BEP Harga $(\mathrm{Rp} / \mathrm{Kg})=\frac{T C}{V_{F C}}$
BEP Produksi $(\mathrm{Kg})=\frac{P-A V C}{P-A}$

Dimana :

$\mathrm{FC}=$ Fixed Cost/Biaya Tetap (Rp/LG/MT)

$\mathrm{VC}=$ Variable Cost/Biaya Variabel (Rp/LG/MT)

$\mathrm{P}=$ Price/Harga Produksi $(\mathrm{Rp} / \mathrm{Kg})$.

$\mathrm{AVC}=$ Average Variable Cost $($ Variabel per unit $=$ Total biaya variabel dibagi total produksi)

TC = Total Cost/jumlah biaya variabel dan biaya tetap usahatani (Rp).

$\mathrm{Y}=$ Yield/hasil produksi $(\mathrm{kg})$.

5). Menganalisis kelayakan Net Present Value (NPV) nilai kini bersih (soekartawi, 2006), sebagai berikut:

$\mathrm{NPV}=\sum_{\mathrm{i}=1}^{\mathrm{n}} \mathrm{NB} \mathrm{i}(1+\mathrm{i})^{-\mathrm{n}}$

Dimana :

$\mathrm{NB}=$ Net Benefit (Benefit Cost) pendapatan bersih

$\mathrm{C}=$ Cost (Total Biaya)

$\mathrm{B}=$ Benefit (Pendapatan Total)

$\mathrm{I}=$ Discount Factor (Tingkat Suku Bunga)

$\mathrm{n}=$ Tahun (Waktu)

Kaidah

NPV $>0$ (nol) $\rightarrow$ usaha layak untuk dikembangkan

$\mathrm{NPV}<0$ (nol) $\longrightarrow$ usaha tidak layak untuk dikembangkan.

$\mathrm{NPV}=0$ (nol) $\longrightarrow$ usaha berada dalam keadaan BEP.

6). Menghitung tingkat bunga yang berlaku kini (Soekartawi, 2006), sebagai berikut :

$\mathrm{IRR}=\mathrm{i}_{1}+\frac{\mathrm{NPV1}}{\mathrm{NPV} 1-\mathrm{NPV} 2} \mathrm{X}\left(\mathrm{i}_{2}-\mathrm{i}_{1}\right)$

Keterangan :

$\mathrm{i}_{1}=$ Discount Faktor Terendah

$\mathrm{i}_{2}=$ Discount Faktor Tertinggi

NPV1 = NPV pada tingkat discount rate tertinggi (Positif).

NPV2 = NPV pada tingkat discount rate terendah (Negatif).

SOCC = Soccial Opportunity Cost of Capital

Kaidah (Tingkat Bunga Berlaku Kini).

IRR > SOCC maka usaha fleksible/layak untuk diteruskan.

IRR = SOCC maka usaha Break Efent poin/Impas.

IRR < SOCC maka usaha tidak fleksible/tidak layak diteruskan.

7). Menghitung tingkat kelayakan (Soekartawi, 2006) dengan menggunakan rumus $\mathrm{Net} B / \mathrm{C}$ :

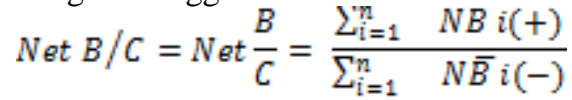

Kaidah

Net $\mathrm{B} / \mathrm{C}>0 \longrightarrow$ berarti usaha tersebut layak dikembangkan.
Net $\mathrm{B} / \mathrm{C}=0 \longrightarrow$ berarti usaha tersebut dalam keadaan BEP.

Net $\mathrm{B} / \mathrm{C}<0 \longrightarrow$ berarti usaha tersebut tidak menguntungkan.

8). Mengetahui respon masyarakat (Darmadi, 2010) :

Jumlah sekor $=\mathrm{T} \times \mathrm{Pn}$

Dimana :

T =Total Jumlah Penulis yang Memilih

Pn = Pilihan Angka Sekor Likert

Untuk mendapatkan hasil interpretasi harus diketahui dulu skor tertinggi (X) dan sekor terendah (Y) untuk item penilaian rumus sebagai berikut

$$
\text { Index }(\%)=\frac{\text { total shor }}{F} \times 100
$$

Dimana :

$\mathrm{Y}=$ skor tertinggi likert $\mathrm{x}$ jumlah penulis

$\mathrm{X}=$ skor terendah likert $\mathrm{x}$ jumlah penulis

Untuk menyelesaikanya kita harus mengetahui interval (jarak) dan interpretasi persen agar mengetahui penilaian dengan metode mencari interval skor persen (1) dengan rumus sebagai berikut :

$$
\begin{aligned}
\text { Interval } & =\frac{100}{\text { jumiah skor }} \\
& =\frac{100}{5} \\
& =20
\end{aligned}
$$

Berikut kriteria interpretasi skornya berdasarkan interval :

$\begin{array}{ccc}\text { No } & \text { Index } & \text { Keterangan } \\ 1 & 0 \%-19,99 \% & \text { Sangat Tidak Setuju } \\ 2 & 20 \%-39,99 \% & \text { Tidak Setuju } \\ 3 & 40 \%-59,99 \% & \text { Netral/ragu-ragu } \\ 4 & 60 \%-79,99 \% & \text { Setuju } \\ 5 & 80 \%-100 \% & \text { Sangat setuju }\end{array}$

\section{HASIL DAN PEMBAHASAN}

\section{A. Analisis Biaya}

Biaya dalam kegiatan usaha dikeluarkan oleh petani dengan tujuan untuk menghasilkan pendapatan yang tinggi bagi usaha yang dikerjakan, dengan mengeluarkan biaya maka petani mengharapkan pendapatan yang setinggi-tingginya melalui peningkatan produksi. Biaya dalam kegiatan usaha terdiri dari biaya tetap (fixed cost) dan biaya variabel (variable cost).

Biaya tetap adalah biaya yang relatif tetap jumlahnya dan harus dikeluarkan walaupun produk yang dihasilkan banyak atau sedikit. Biaya tidak tetap (variable cost) adalah biaya yang sifatnya berubahubah tergantung dari besar kecilnya produksi yang dihasilkan. Sedangkan biaya total adalah penjumlahan dari biaya tetap dan biaya variabel.

Dalam penelitian ini analisis biaya usaha yang diperhitungkan adalah pada MT gadu (Juni September) Tahun 2020. Untuk setiap tahunnya terdapat 2 kali tanam Bawang Merah. Berikut komponen biaya usaha Budidaya Bawang Merah di Kecamatan Belitang III Kabupaten OKU Timur :

\section{Biaya tetap}

Biaya tetap (fixed cost) adalah biaya yang relatif tetap jumlahnya dan harus dikeluarkan walaupun produk yang dihasilkan banyak atau sedikit dan tidak 
habis dalam satu kali proses produksi. Dalam penelitian ini yang dikelompokkan ke dalam biaya tetap adalah biaya penyusutan alat.

Analisis usaha pada penelitian ini didihitung adalah pada MT gadu tahun 2020. Dalam setiap tahunnya terdapat dua kali waktu tanam Bawang merah. Berikut komponen biaya tetap usaha Budiya Bawang Merah di Kecamatan Belitang III Kabupaten OKU Timur, sebagai berikut :

Tabel 2. Biaya Tetap Usaha Budidaya Bawang Meran di kecamatan Belitang III Kabupaten OKU Timur.

\begin{tabular}{llrc}
\hline No & \multicolumn{1}{c}{ Uraian Biaya } & \multicolumn{1}{c}{ Nilai } & \multicolumn{1}{c}{ Satuan } \\
\hline 1. & Biaya Penyusutan Alat & 48.853 & $(\mathrm{Rp} / \mathrm{LL} / \mathrm{MT})$ \\
& Biaya Sewa Lahan & 6.000 .000 & $(\mathrm{Rp} / \mathrm{LL} / \mathrm{MT})$
\end{tabular}

\begin{tabular}{cccc}
\hline 2. & Total Biaya Tetap & 6.048 .853 & (Rp/LL/MT) \\
\hline
\end{tabular}

Sumber : Data Olahan Primer, 2020.

Berdasarkan hasil perhitungan pada tabel diatas diketahui bahwa biaya tetap usaha budidaya bawang merah terdiri dari biaya penyusutan alat sebesar $\mathrm{Rp}$ 48.853/MT, dan biaya sewa lahan sebesar Rp 6.048.853/MT sehingga total biaya tetap usaha Budidaya Bawang Merah di Kecamatan Belitang III pada MT adalah sebesar Rp 6.048.853 /MT.

\section{Biaya Variabel}

Biaya tidak tetap (variable cost) adalah biaya yang sifatnya berubah-ubah yang digunakan sebagai biaya operasional usaha dan biasanya habis dalam satu kali musim tanam. Biaya variabel terdiri dari biaya operasional digunakan untuk operasional usaha budidaya bawang merah dan biaya tenaga kerja selama satu kali musim tanam yaitu pada MT Tahun 2020. Berikut komponen biaya variabel usaha Budidaya Bawang Merah di Kecamatan belitang III Kabupaten OKU Timur, sebagai berikut :

Tabel 3. Biaya Variabel Usaha Budidaya Bawang Merah di Kecamatan Belitang III Kabupaten OKU Timur.

\begin{tabular}{cccc}
\hline No & Uraian Biaya & Nilai & Satuan \\
\hline \multirow{2}{*}{1.} & Biaya Operasional & 203.388 .000 & $(\mathrm{Rp} / \mathrm{LL} / \mathrm{MT})$ \\
& Biaya Tenaga Kerja & 19.030 .000 & $(\mathrm{Rp} / \mathrm{LL} / \mathrm{MT})$ \\
\hline \multirow{2}{*}{. } & Total Biaya Variabel & 222.418 .000 & $(\mathrm{Rp} / \mathrm{LL} / \mathrm{MT})$ \\
\hline
\end{tabular}

Sumber : Data Olahan Primer, 2020.

Berdasarkan hasil perhitungan pada tabel diatas diketahui bahwa biaya variabel usaha budidaya Bawang merah digunakan untuk biaya operasional dan biaya tenaga kerja. Dalam satu musim tanam rata-rata luas lahan yang diolah 3 Ha. Biaya operasional usaha antara lain digunakan untuk membeli bibit rata-rata sebanyak $3000 \mathrm{~kg}$, membeli Kapur Pertanian rata-rata sebanyak $4.200 \mathrm{Kg}$, Petroganik rata-rata sebanyak $4.200 \mathrm{Kg}$, SP36 rata-rata sebanyak $4.200 \mathrm{Kg}$, NPK rata-rata sebanyak $4200 \mathrm{Kg}$, membeli fungisida, bakterisida, insektisida, pupuk daun, KCL Cair yang habis dalam sekali proses produksi, membeli mulsa yang rata-rata sebanyak 30 Gulung, dan membeli bensin untuk kultifator sebanyak 60 Liter.

Sedangkan biaya tenaga kerja digunakan untuk proses dari Pengolahan Lahan, tanam, penyemprotan, penyiangan, dan pemanenan dalam satu musim tanam lahan $3 \mathrm{Ha}$. sehingga besarnya biaya tenga kerja usaha budidaya bawang merah adalah sebesar Rp 19.030.000. Adapun besarnya biaya variabel usaha budidaya bawang merah yang terdiri dari biaya opersional dan biaya tenaga kerja adalah sebesar Rp 222.418.000/MT.

\section{Biaya Total Produksi}

Biaya total dalam usaha Budidaya Bawang Merah di Kecamatan Belitang III terdiri dari biaya tetap ditambah dengan biaya variabel. Besarnya biaya total yang dikeluarkan dalam usaha budidaya bawang merah di Kecamatan Belitang III dapat dilihat pada tabel sebagai berikut :

Tabel 4. Biaya Total Usaha Budidaya Bawang Merah di Kecamatan Belitang III Kabupaten OKU Timur.

\begin{tabular}{clrc}
\hline No & \multicolumn{1}{c}{ Uraian Biaya } & \multicolumn{1}{c}{ Nilai } & \multicolumn{1}{c}{ Satuan } \\
\hline 1 & Biaya Tetap & & \\
& a. Biaya Penyusutan Alat & 48.853 & $(\mathrm{Rp} / \mathrm{LL} / \mathrm{MT})$ \\
& b. Biaya Sewa Lahan & 6.000 .000 & $(\mathrm{Rp} / \mathrm{LL} / \mathrm{MT})$ \\
2 & Biaya Variabel & & \\
& a. Biaya Operasional & 203.388 .000 & $(\mathrm{Rp} / \mathrm{LL} / \mathrm{MT})$ \\
& b. Biaya Tenaga Kerja & 19.030 .000 & $(\mathrm{Rp} / \mathrm{LL} / \mathrm{MT})$ \\
\hline 3 & Total Biaya Produksi & 228.466 .853 & $(\mathrm{Rp} / \mathrm{LL} / \mathrm{MT})$ \\
\hline
\end{tabular}

Sumber : Data Olahan Primer, 2020.

Berdasarkan hasil perhitungan pada tabel diatas diketahui bahwa biaya tetap usaha Budidaya Bawang Merah di Kecamatan Belitang III dalam satu kali musim tanam $\mathrm{Rp} 48.853$ untuk baya penyusutan alat dan Rp 6.000.000 untuk biaya sewa lahan , besarnya biaya variabel usaha dalam satu kali musim tanam adalah sebesar Rp 203.388.000 untuk biaya operasional dan Rp 19.030.000 untuk Biaya Tenaga Kerja. Sehingga total biaya usaha Budidaya Bawang Merah di Kecamatan Belitang III Kabupaten OKU Timur dalam satu kali musim tanam adalah sebesar Rp 228.466.853 (Rp/LL/MT).

B. Luas Lahan, Harga Sewa, Penerimaan,Pendapatan, dan Break Event Point (BEP)

Bapak Kristiono menjelaskan bahwa dalam satu kali musim tanam umumnya luas lahan yang diolah adalah seluas $3 \mathrm{Ha}$. Dalam satu tahun 2 kali tanam Bawang merah, nilai sewa, penerimaan, pendapatan dan BEP usaha budidaya bawang merah dalam satu kali musim tanam dapat dilihat pada tabel sebagai berikut :

Tabel 5. Luas lahan, Penerimaan, dan Pendapatan Usaha Budidaya Bawang merah di 
kecamatan Belitang III Kabupaten OKU Timur.

\begin{tabular}{clcr}
\hline No & \multicolumn{1}{c}{ Uraian } & Satuan & \multicolumn{1}{c}{ Keterangan } \\
\hline 1 & Lahan & Ha & 3 \\
2 & Sewa lahan & (Rp/LL/MT) & 6.000 .000 \\
3 & Penerimaan & (Rp/LL/MT) & 432.000 .000 \\
4 & Biaya Produksi & (Rp/LL/MT) & 228.466 .853 \\
5 & Pendapatan & $($ Rp/LL/MT) & 203.533 .147 \\
6 & BEP (Harga) & $(\mathrm{Rp} / \mathrm{Kg})$ & 10.577 \\
7 & BEP (Produksi) & $(\mathrm{Kg} / \mathrm{LL})$ & 623 \\
\hline
\end{tabular}

Sumber : Data Olahan Primer, 2020.

Berdasarkan hasil perhitungan pada tabel diatas diketahui bahwa jumlah luas lahan yang diolah satu kali musim tanam bawang merah adalah seluas $3 \mathrm{Ha}$ dan besarrya nilai sewa lahan adalah sebesar $\mathrm{Rp}$ 6.000.000/MT dan dpenerimaan usaha budidaya bawang merah di kecamatan belitang III Kabupaten OKU Timur sebesar Rp 432.000.000/MT. Biaya total yang dikeluarkan adalah sebesar Rp 228.466.853/MT sehingga diperoleh pendapatan dalam satu kali musim tanam bawang merah di Kecamatan Belitang III Kabupaten OKU Timur adalah sebesar Rp 203.533.147/MT.

Sedangkan Break Event Point atau BEP (Harga) harga minimal yang harus dikeluarkan supaya usaha budidaya bawang merah tidak mengalami kerugian adalah Rp 10.577/Kg, dan Break Event Point BEP (Produksi) produksi minimal dalam budidaya bawang Merah di Kecamatan Belitang III yang harus dikeluarkan supaya usaha budidaya bawang merah tidak mengalami kerugian adalah adalah sebesar 623 $\mathrm{Kg}$.

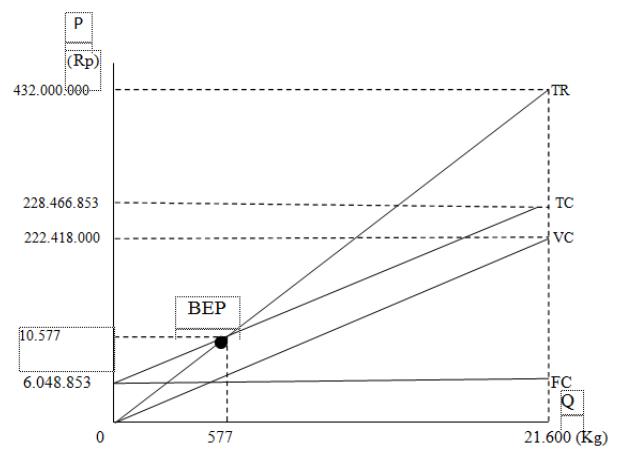

Gambar 2. Kurva BEP (Break Event Point)

\section{Analisis Kelayakan Usaha}

Dalam penelitian ini analisis kelayakan usaha dihitung selama 10 tahun usaha dari 5 tahun usaha telah berjalan dan 5 tahun prospek usaha ke depannya. Adapun 5 tahun usaha telah berjalan yaitu dimulai dari tahun 2015 sampai dengan tahun 2020. Sedangkan perkiraan 5 tahun usaha ke depannya yaitu tahun 2020 sampai dengan tahun 2025. Perhitungan 5 tahun usaha yang telah berjalan yaitu dari tahun 2015 sampai 2020 menggunakan Compounding Factor dan perhitungan usaha 5 tahun ke depan yaitu tahun 2021 sampai 2025 menggunakan Discont Factor. Untuk menganilisis kelayakan usaha usaha budidaya bawang merah di Kecamatan Belitang III ini maka analisis yang digunakan adalah analisis NPV, IRR dan Net B/C.

\section{Analisa NPV}

Net Present Value (NPV) atau nilai sekarang bersih adalah analisis manfaat finansial yang digunakan untuk mengukur layak tidaknya suatu usaha dilaksanakan dilihat dari nilai sekarang (present value). Kriteria kelayakan dari usaha ini adalah: proyek layak jika NPV lebih besar dari nol (positif) dan sebaliknya proyek tidak layak jika NPV nilainya lebih kecil dari nol (negatif).

Hasil analisis diketahui bahwa nilai NPV diperoleh dengan menghitung pendapatan usaha budidaya bawang merah selama 10 tahun usaha yaitu tahun 2015, tahun 2016 dan tahun 2017 tahun 2018 tahun 2019 tahun 2020 yang dihitung dengan menggunakan Compounding Faktor dan pendapatan usaha pada tahun 2021, tahun 2022 dan tahun 2023 tahun 2024 tahun 2025 dengan menggunakan Discont Faktor dengan tingkat suku bunga bank acuan rata-rata sebesar 7\% per tahun maka diperoleh nilai NPV adalah sebesar Rp 170.315.520. Berdasarkan analisis diperoleh nilai NPV > 0 , Hal ini menunjukan bahwa usaha usaha budidaya bawang merah di Kecamatan Belitang III OKU Timur ini layak secara financial (faesibel) untuk diteruskan.

\section{Analisa IRR (Internal Rate of Return)}

IRR menunjukkan kemampuan suatu investasi atau usaha dalam menghasilkan return atau tingkat keuntungan yang bisa dipakai. IRR menunjukkan tingkat rata-rata keuntungan tahunan bagi perusahaan yang melakukan investasi dan dinyatakan dalam satuan persen. Kriteria yang dipakai untuk menunjukkan bahwa suatu usaha layak dijalankan adalah jika nilai IRR lebih besar dari tingkat suku bunga yang berlaku pada saat usaha tersebut diusahakan. Jika IRR lebih kecil dari tingkat suku bunga maka usaha yang direncanakan tidak layak secara finansial. Cara mengukur IRR adalah dengan melakukan percobaan yang terus - menerus menggunakan metode interpolasi di antara tingkat suku bunga yang menghasilkan NPV negatif.

Berdasarkan nilai NPV positif (+) adalah sebesar Rp 170.315.520. Untuk mencari NPV negative terkecil maka diperoleh dengan melakukan percobaan yang terus - menerus menggunakan metode interpolasi diantara tingkat suku bunga sehingga menghasilkan NPV negatif. Berdasarkan analisis yang dilakukan maka diperoleh nilai NPV negatif (-) terkecil dengan nilai interest $13 \%$ adalah sebesar Rp (15.877.602).

Berdasarkan hasil analisis pendapatan usaha budidaya bawang merah selama 10 tahun usaha yaitu tahun 2015, tahun 2016, tahun 2017, tahun 2018, tahun 2019, dan tahun 2020 yang dihitung dengan menggunakan Compounding Faktor dan pendapatan usaha pada tahun 2021, tahun 2022, tahun 2023, tahun 
2024 dan 2025 dengan menggunakan Discont Faktor dengan menggunakan acuan suku bunga rata-rata $7 \%$ per tahun, maka diperoleh nilai IRR usaha budidaya bawang merah adalah sebesar $12,4 \%$ yang berarti nilai IRR lebih besar daripada nilai SOCC (Social Opportunity Cost of Capital) atau tingkat suku bunga bank acuan yaitu rata-rata sebesar $7 \%$ per tahun. Hal ini menunjukan bahwa rata-rata keuntungan usaha budidaya bawang merah adalah sebesar 12,4\% per tahun. Nilai IRR yang lebih besar dari SOCC ini menunjukan bahwa usaha Budidaya Bawang Merah di Kecamatan Belitang III Kabupaten OKU Timur layak (feasible) secara finansial untuk dikembangkan.

\section{Analisa Net $\mathbf{B} / \mathbf{C}$}

Net Benefit Cost adalah penilaian yang dilakukan untuk melihat tingkat efisiensi penggunaan biaya berupa perbandingan jumlah NPV yang positif dengan NPV yang negatif dan ini menunjukkan gambaran berapa kali lipat benefit akan kita peroleh dari cost yang kita keluarkan. Kriteria ini memberikan pedoman bahwa suatu proyek akan dipilih apabila nilai (Net $B / C>1$ ), sebaliknya bila suatu proyek memberikan nilai $($ Net $B / C<1)$, maka proyek tidak akan diterima (diteruskan). Pendapatan usaha budidaya bawang merah selama 10 tahun usaha yaitu tahun 2015, tahun 2016, tahun 2017, tahun 2019 dan tahun 2020 yang dihitung dengan menggunakan Compounding Factor dan pendapatan usaha pada tahun 2021, tahun 2022, tahun 2023, tahun 2024, dan tahun 2025 dengan menggunakan Discont Faktor dengan menggunakan acuan suku bunga rata-rata $7 \%$ per tahun.

Nilai Net B/C diperoleh dengan menjumlahkan nilai Present Value Benevit (PVB) positif (+) kemudian hasilnya dibagi dengan nilai PVB negatif (-). Berdasarkan hasil perhitungan, diperoleh jumlah dari Present Value Benevit (PVB) yang positif adalah sebesar Rp 609.945.711. Nilai PVB negatif adalah sebesar 363.191.121 sehingga diperoleh nilai Net B/C adalah sebesar 1,68. Nilai net B/C 1,68 artinya bahwa setiap Rp 1 modal yang dikeluarkan untuk usaha Budidaya bawang merah maka akan diperoleh keuntungan bersih setelah didiskonto (dikenai suku bunga bank) sebesar Rp 1,68. Nilai Net B/C > 1 berarti usaha Budidaya Bawang Merah di Kecamatan Belitang III Kabupaten OKU Timur layak (feasible) secara financial untuk dikembangkan.

Tabel 6. Analisis Kelayakan Usaha Budidaya Bawang Merah di Kecamatan Belitang III Kabupaten OKU Timur, Tahun 2016-2021.

\begin{tabular}{llcr}
\hline No & Uraian & Satuan & Nilai \\
\hline 1. & NPV & Rp & 170.315 .520$. \\
2. & IRR & $\%$ & 12,49 \\
3. & Net B/C & & 1,68 \\
\hline
\end{tabular}

Sumber : Data Olahan Primer, 2020.

Berdasarkan perhitungan analisis NPV, IRR dan Net B/C yang telah dilakukan menunjukan bahwa usaha budidaya bawang merah di Kecamatan Belitang III Kabupaten OKU Timur layak (feasible) secara financial untuk dikembangkan.
D. Respon Masyarakat Terhadap Rencana Pengembangan Budidaya Bawang Merah di Kecamatan Belitang III

Menurut Swastha dan Handoko (1997), respon adalah predisposisi (keadaan mudah terpengaruh) untuk memberikan tanggapan terhadap rangsangan lingkungan, yang dapat memulai atau membimbing tingkah laku orang tersebut. Untuk mengetahui respon masyarakat terhadap berdirinya kampung organik dapat dilihat pada tabel di bawah ini:

Tabel 7. Respon Masyarakat Terhadap Rencana Pengembangan Budidaya Bawang Merah.

\begin{tabular}{ccccc}
\hline No & Uraian & $\begin{array}{c}\text { Jumlah } \\
\text { Responden }\end{array}$ & Skor & $\begin{array}{c}\text { Persentase } \\
(\%)\end{array}$ \\
\hline 1. & Sangat Tidak Setuju & 0 & 0 & 0 \\
2. & (STS) & 0 & 0 & 0 \\
3. & Tidak Setuju (TS) & 3 & 9 & 10,3 \\
4. & Netral (N) & 23 & 88 & 79,3 \\
5. & Setuju (S) & 3 & 15 & 10,3 \\
\hline
\end{tabular}

Berdasarkan hasil wawancara di lapangan dengan menggunakan kuisioner terhadap 29 responden, respon masyarakat terhadap rencana pengembangan budidaya bawang merah ditunjukkan pada tabel di atas yaitu 79,3\% masyarakat setuju dan $10,3 \%$ sangat setuju dengan rencana pengembangan budidaya bawang merah namun $10,3 \%$ netral serta $0 \%$ tidak setuju dan $0 \%$ sangat tidak setuju dengan rencana pengembangan budidaya bawang merah.

Masyarakat desa Dadi Rejo yang Merupakan desa di sekitar tempat budidaya bawang merah memberikan respon Setuju karena melihat kedaan wilayah yang cocok untuk di tanami bawang merah seperti Tanahnya subur, Pengairan dari irigasi yang baik, Cuaca dan iklim yang cocok untuk budidaya bawang merah, Memiliki penyinaran sinar matahari lebih dari 75\% sehingga Masyarakat Desa Dadi Rejo Setuju Dengan Adanya pengembangan budidaya bawang merah. Dengan demikian diperlukan pendekatan khusus terhadap masyarakat dan diperlukan sosialisasi-sosialisasi seputar usaha budidaya bawang merah supaya masyarakat semakin paham dan mengerti tentang bawang merah. Masyarakat yang setuju disarankan untuk melakukan program pengembangan budidaya bawang merah di Kecamatan Belitang III Kabupaten OKU Timur.

\section{V.KESIMPULAN DAN SARAN}

\section{A. Kesimpulan}

Berdasarkan hasil penelitian ini, maka kesimpulan yang dapat dimbil adalah sebagai berikut :

1. Usaha budidaya bawang merah dalam satu kali musim tanam mengeluarkan biaya produksi sebesar Rp 410.323.853 diperoleh penerimaan sebesar Rp 475.200.000 sehingga diperoleh pendapatan sebesar Rp 64.876.147 dengan nilai BEP (harga) sebesar Rp 18.996/kg dan BEP (produksi) sebesar $2.251 \mathrm{~kg}$.

Selanjutnya usaha budidaya bawang merah di Keecamatan Belitang III Kabupaten OKU layak 
(feasible) secara finansial untuk dikembangkan, hal ini dapat diketahui dari perhitungan nilai NPV sebesar Rp 170.315.520, nilai IRR sebesar $12,49 \%$ dan nilai Net B/C sebesar 1,68.

2. Respon masyarakat terhadap rencana pengembangan budidaya bawang merah adalah siap/setuju dengan nilai index 79,3\%. Masyarakat desa Dadi Rejo yang Merupakan desa di sekitar tempat budidaya bawang merah memberikan respon Setuju karena melihat kedaan wilayah yang cocok untuk di tanami bawang merah seperti Tanahnya subur, Pengairan dari irigasi yang baik, Cuaca dan iklim yang cocok untuk budidaya bawang merah, Memiliki penyinaran sinar matahari lebih dari $75 \%$ sehingga Masyarakat Desa Dadi Rejo Setuju Dengan Adanya pengembangan budidaya bawang merah.

\section{B. Saran}

Adapun saran berdasarkan penelitian yang telah dilaksanakan pada usaha pengembangan budidaya bawang merah perlu dilaksanakan dengan sebaikbaiknya sehingga dapat menjadi contoh bagi masyarakat lainnya. Selain itu hasil penelitian ini juga dapat memberikan referensi bagi pembaca untuk melakukan penelitian selanjutnya.

\section{DAFTAR PUSTAKA}

Drektorat Jendral Hortikultura. 2004. Konsumsi Bawang Merah (internet). Jakarata. (Diunduh 12 Maret 2020). Tersedia pada : www.litbang.deptan.go.id

Laude, S. Dan A. Hadid, 2007. Respon Tanaman Bawang Merah Terhadap Pemberian Pupuk Organik Cair Lengkap. Jurnal Agribisnis.
Rahayu, e, dan Berlian,N. 1999.Bawang Merah. Penebar Swadaya, Jakarta.

Rukmana, R, 1995. Bawang Merah Budidaya dan Pengolahan Pasca Panen. Kanisius, Yogyakarta.

Sitepu, B.H., S. Ginting Marianti. 2013. Respon Pertumbuhan dan Produksi Bawang Merah (Allium ascalonicum L. Var Tuk Tuk) Asal Biji Terhadap Pemberian Pupuk Kalium dan Jarak Tanam.Jurnal Online Agroteknologi.

Sjarkowi, F. dan Marwan, S. Manajemen Agribisnis. CV. Baldad Grafitti. Prees. Palembang.

Sjarkowi, F. 2010. Manajemen Pembangunan Agribisni. Baldad Grafitti. Prees. Palembang.

Soekartawi. 2002. Analisis Usaha. Universitas Indonesia. Jakarta

Suratiyah. 2006. Ilmu Usahatani. PT. Penebar Swadaya. Jakarta.

Tjitrosoepomo, Gembong. 2010. Taksonomi Tumbuhan Spermatophita. Yogyakarta : Gajah Mada Uiversity Prees.

Wibowo, singgih. 2006. Budidaya Bawang Merah, Bawang Putih, dan Bawang Bombay. Jakarta. 